\title{
From the Series Editors
}

\section{Origins of the Project}

Since its inception in 2006 Russia's Great War and Revolution, 1914-22 has taken shape through the collaboration of an international community of historians interested in the history of World War I's understudied eastern theater. Timed to coincide with the centenary of the Great War-and, by extension, the revolutions it helped unleash-this series responds to several developments in the historiography of the Russian Empire, its Soviet successor, and the Great War as a whole.

During a century of scholarly and popular discussion about the First World War, the "Russian" part of the conflict received little sustained attention until after 1991. In the former USSR, the war stood in the shadow of the revolutions of 1917 and the subsequent Civil War that resulted in the formation of the Soviet Union; most of all, it was eclipsed by the apotheosization after 1945 of the Great War of the Fatherland, the victory over Nazi Germany, as the defining moment in Soviet history. As a result, the First World War appeared as the final folly of an outmoded bourgeois-noble autocracy, doomed to collapse by the laws of history. Non-Soviet scholars, often hampered by restricted access to archival collections, downplayed the Russian war experience for other reasons. Specialists in the history of the late empire or early Soviet order tended to see the war as either the epilogue to the former or the prologue to the latter. Western historians often focused on the war experience of their own statesmost often Britain and its imperial possessions, France, or Germany-or on a welter of issues bequeathed by the outbreak of the war in 1914 and the peacemaking in the years following 1918. These issues included most notably the vexed question of Germany's "war guilt," encoded in Article 231 of the Versailles Treaty, which has continued to provoke a lively and contentious discussion in the intervening 100 years.

The disintegration of the Soviet Union by the end of 1991 cast the history of the Soviet state and the late empire in a different light. Long-closed archivesparticularly for military and international history-became relatively accessible to post-Soviet and Western scholars. As important, opportunities opened quickly for collaboration and dialogue between historians in Russia and their colleagues abroad, fostering new research and interpretations that would have been impossible or inconceivable before the late 1980s. Likewise, the dramatic 
changes of the era led scholars in- and outside the former USSR to re-examine long-held assumptions about the Soviet state and its origins, accompanied by renewed debate over the viability of the Russian Empire as it adapted to the challenges of modernity. As part of this general re-evaluation, Russia's Great War became a subject of study in its own right. By the early 21st century, the war years came to be seen as what Peter Holquist termed "a continuum of crisis." Rather than an abrupt rupture between juxtaposed imperial and Soviet orders, the war now appears not just as a powerful force of disruption, but also a period of intense mobilization-as in the other combatant statesthat produced the modes and the "gaze" of statecraft, mass culture, and social control often associated with the totalitarian/authoritarian states of the interwar and Cold War years. Such practices include the nationalization of economies, the increasing application of technology to surveillance, reaching farther than before into the "private" sphere, but also such issues as displaced or refugee populations, racialized nationalist ideologies, and the development of such means as mass propaganda in support of building a utopia in our time.

All of these contexts have been brought into sharp focus by the centenary of the Great War. This occasion has engendered a great deal of scholarly and popular interest, attested by the gathering stream of books, exhibits, and memorials that will, over the coming years, mark the milestone anniversaries in the conflict's history: the war's outbreak in the summer of 1914 and key moments enshrined in the historical memories of the combatant states. All of the one-time enemies will honor the millions of dead, wounded, incapacitated, and displaced by the first "war to end all wars." For the first time, Russians will take part in these rites of commemoration. At the end of 2012, the Russian Federation declared August 1 the annual "Day of Remembrance for the Victims of the First World War" (Den' pamiati zhertv Pervoi mirovoi voiny), first observed in 2013. Similarly, having long been consigned to the margins of the dominant narratives on the First World War, Russia's part in and experience of the Great War has become the focus of a substantial body of new scholarship. This collection forms part of that new contribution to the international understanding of that conflict.

If the concept behind Russia's Great War and Revolution reflects recent trends in the historiography on the war's meaning for Russian history, its form draws on earlier examples of the sort of international collaboration that have become increasingly possible since the late 1980s. Each of the general editors and many members of the editorial collective had participated in similar partnerships, albeit on a smaller scale. Such projects included two volumes on Russian military history that enlisted the best specialists from the international community. Eric Lohr and Marshall Poe edited The Military and Society in Russia (Brill, 2002), while Reforming the Tsar's Army (2004), edited by Bruce Menning and David Schimmelpenninck van der Oye, appeared with the Wilson Center and Cambridge University Press in 2004. Other participants in this project had taken part in two other similar collections. In 2005, Routledge 
published The Russian Revolution of 1905: Centenary Perspectives, co-edited by Jonathan Smele and Anthony Heywood. That year also saw the publication by Brill of volume 1 of The Russo-Japanese War in Global Perspective: World War Zero; volume 2 came out two years later. Both were overseen by Menning, Schimmelpenninck, and John W. Steinberg. Each of these collections provided instructive examples of how to organize and produce the broad collaborative effort that has led to the appearance of Russia's Great War and Revolution.

\section{Aims}

Recognizing both the growing scholarly interest in Russia's Great War and the occasion presented by the successive centenaries of the First World War and the Russian revolutions, the editors of this collection have sought to assemble the best current international scholarship on the conflict. Ideally, they have oriented this collection toward several audiences. For those in the academy-scholars, undergraduates and graduate students-we offer a series of edited collections, varying in format and approach, that will provide a "snapshot" of the current state of the field. As a reflection of existing scholarly interests and debate, these materials will by default indicate those topics and issues demanding further attention. Editorial teams agreed on the optimal structure, periodization, and approach taken in their respective volumes. As a consequence, depending on the topic covered, some volumes provide a largely narrative treatment of events-for instance, military operations and engagements-or of developing issues, as occurs in the volume on international relations. Others, most often dealing with the "home front" or Russia as an empire, will present chapters that examine specific problems, groups, or regions.

In addition to addressing our academic communities, the editors seek also to engage non-professional readers in the general public, including secondary school students. To this end, as a supplement to the books in this collection, the larger editorial collective have created a dedicated website with such supporting materials as maps, illustrations, sound files, and moving images. Further, the editors plan to house on the web-site special sections devoted to summaries of the published findings and instructional guides to aid teachers in developing school and lesson plans. Finally, alongside its appearance in book form, the series will also be available on the internet through the Project MUSE scholarly database. Readers with access to that platform will be able to conduct searches in and download entire books or individual chapters as they require. In addition to benefiting scholars interested in Russia during the Great War and revolutions, the MUSE edition will provide instructors with a ready trove of materials which can provide specific readings, as well as a valuable research resource for their students. 


\section{Conceptualization and Organization}

The volumes in this collection reflect the current state of scholarship on Russia's experience of the "long" Great War, spanning the First World War, the revolutions, and the Russian Civil War. Editors have sought to cover all the significant aspects of Russia's history during 1914-22, so far as current expertise permits, under a series of thematic rubrics. These cover a wide range of subjects, including the experience of the soldiers involved, as well as of the urban and rural populations on the "home front"; the course of international relations, both formal and non-governmental; the implications of war and revolution for the empire as a polity incorporating a broad variety of national and confessional populations bound to the imperial "center" by distinctive administrative and legal regimes; and the impact of prolonged "total war" on the cultural, religious, and intellectual life of the region. Looking outward beyond the territories of the Russian Empire/USSR themselves, other volumes address the perspectives of the Central Powers during the Great War, the effects of war and civil war in Siberia and the Far East, the lengthening "arc of revolution" through the peripheries of the former empire and beyond to the global south and New World in the years following 1917, and, finally, the repercussions of total wars and revolution on ideas about and performance of gender, sexuality, and the sphere of intimacy in Russian society. Of course, throughout, the use of the term "Russia" and its inflections connotes, unless otherwise stated, the territory and populations housed within the boundaries of the Russian Empire in 1914.

Given the breadth of the subject matter and the renewed interest of historians in Russia's Great War, this collection does not aspire to offer a comprehensive narrative history of the war, nor is it meant to serve as an encyclopaedia of issues, events, and persons associated with the war and revolutions. Rather, it seeks to provide clear representation of current scholarly interests and debates, while indicating areas in need of more research. Thus, readers will find relatively few articles on the economic history of either the war or the Civil War. Likewise, many areas of international relations remain uncovered, not least the formation of policy-making institutions in the successor states to the Russian Empire. Those interested in the revolutionary period will find the "workers' movement" far less prominent in this collection than would have been the case for much of the late 20th century, while the peasantry and Russia's regions have begun to receive comparatively greater attention.

As noted previously, an underlying aim of this series is to encourage further research into areas as yet insufficiently covered in current scholarship. Thus, despite the increasing prevalence of the "imperial turn" in our historiography, the impact of the war, revolutions, and Civil War in Russia's imperial borderlands has only begun recently to command the interest that it warrants. By the same token, like their counterparts for the history of other countries, 
specialists on 20th-century Russia have yet to delve deeply into the manifold aspects of religion and religiosity in the wartime Russian Empire, from popular or folk religion and religious practice, through the high politics of spiritual institutions, to the effects of war and turmoil on currents in theology and religious philosophy that had begun to run so strong during the "Silver Age."

Finally, throughout the long process that led to the appearance of this series, the editorial teams have sought to avoid the imposition of an explicit interpretive agenda, in the interests of conveying a sense of current areas of debate and consensus in our historical literature. Thus, while the periodization of 1914-22-i.e., the years spanning the Russian Empire's entry into war through two revolutions, civil war, and the formation of the Soviet statehas taken hold with many historians, others continue to maintain that such an approach risks flattening or downplaying the significance of 1917 and its consequences for the area's subsequent history. In the interest of providing as clear as possible a reflection of the current "state of play," these volumes house a variety of interpretations and periodizations, inviting readers to draw their own inferences and conclusions from the evidence and arguments on offer.

\section{Process}

From the beginning, editors have viewed Russia's Great War and Revolution as a truly global project, incorporating perspectives from historians across Europe, North America, Russia, Asia, and Australia. In addition to the subject matter treated in the volumes' contents, this global approach informed the composition of the editorial teams that oversaw the production of each volume. Each of these groups included members from North America, Russia, and the United Kingdom or continental Europe. Where the contents required it-for instance, in the book dealing with Asia, scholars from elsewhere joined the editorial team. In the interests of reaching the broadest possible international audience, the editors agreed on English as the language for the series, with the intention of publishing a parallel Russian-language edition when feasible. The articles in these volumes consist both of submissions in response to a widely circulated open call and invited contributions. Papers were selected in a two-stage process involving initial vetting by editorial team-members, then evaluation by the full editorial board. Throughout, editors strove for the greatest possible inclusiveness, with the result that the articles in the series represent a broad variety of scholars, ranging from graduate students through all ranks of the academic cursus honorum.

The project and its publication took shape through a series of editorialboard meetings that began at the University of Aberdeen in the summer of 2008. A meeting at the University of Wisconsin-Madison the following summer resulted in agreement on the thematic areas to be addressed by separate volumes, in addition to provisional topical headings for each volume. At Uppsala University in 2010, board-members refined outlines of desired contents 
for each volume, leading to a public call for papers the following autumn. From that point forward, editors pursued submissions, while project representatives participated in the presentation of project overviews and draft articles at the annual conventions of the Association for Slavic, East European, and Eurasian Studies (ASEEES), the Study Group of the Russian Revolution, the British Association for Slavonic and East European Studies (BASEES), the Southern Conference on Slavic Studies, and the 2010 Stockholm meeting of the International Council for Central and East European Studies (ICCEES).

The chapters contained in the volumes comprising Russia's Great War and Revolution have undergone an intensive multi-stage review process, overseen collectively by the 30 -odd members of the full editorial board. The publisher also solicited a peer assessment of the project description and design; the resulting review yielded important and helpful suggestions, as did consultation with the project's advisory board. Next, editorial teams for individual volumes jointly assessed contributions. To select papers for inclusion in individual volumes and to prepare the latter for publication, the editorial board adopted a two-tier review exercise. Editorial teams were paired according to areas of overlapping interest or approach. Each of the teams would read and critique the contents for the other's volume, followed by a general discussion involving the entire editorial board. Finally, after the completion of revisions, that volume's editorial team sent it on to the general editors, who solicited anonymous peer reviews for final review. Once the volume editors addressed any critiques or suggestions from these last reviews, the general editors submitted the volume to the publisher for production.

\section{Acknowledgments}

In the eight years from its origins to the first appearance of its results, this project benefited immeasurably from the support of many people and institutions. The editorial board owes a special debt of gratitude to Alice D. Mortenson from Minneapolis, Minnesota for her unstinting support of and generosity to this undertaking, not least through the Alice D. Mortenson/Petrovich Chair of Russian History. This resource proved indispensable in making possible several successive editorial meetings. Special thanks are also due to Scott Jacobs of Houston, Texas, who provided significant support to this project for more than five years. His contributions helped ensure the success of the summer editorial meetings at the University of Wisconsin-Madison in 2012. Both donors also made possible many of the translations in the collection.

The editorial board also benefited from the support of several universities and departments. Significant financial support was provided by the University of Aberdeen, Scotland, through the School of Divinity, History and Philosophy, the College of Arts and Social Sciences, and the 
Principal's Interdisciplinary Fund to facilitate our inaugural board meeting at Aberdeen in 2008 and our fifth full meeting in 2014. The Department of History at the University of Wisconsin-Madison hosted the 2009 and 2012 editorial-board meetings; Nicole Hauge played a key role in arrangements for the visitors to Madison on both occasions. In addition, we benefited from the support of the university's Anonymous Fund and the office of the Dean of the College of Letters and Science. Our colleagues in the Department of History at Uppsala University in Sweden gave us the use of their facilities and meeting-space in the summer of 2010, providing an excellent and hospitable environment for our discussion. Many of the home institutions of the editorial board also contributed travel costs and meeting-space for the compilation of several volumes in this collection; some helped underwrite some translation costs as well.

Several other groups and institutions played an important role in the gestation of this series. The Kennan Institute of the Woodrow Wilson International Center Scholars, particularly Associate Director William Pomeranz, has actively supported the project since its outset. Grants to support our editorial meetings were provided by the British Academy, BASEES, and the Great Britain Sasakawa Foundation. The German Historical Institute in Moscow very kindly sponsored the translation into English of chapters written in German. The Study Group on the Russian Revolution served as an important venue for the development of many of the chapters, particularly from British and European contributors, that appear in these volumes. George Fowler and Vicki Polansky of Slavica Publishers have proven the ideal partners in this lengthy process, offering sage counsel, clear deadlines, exemplary patience, professionalism, and rigor, all of which have made the production process run with an enviable dispatch and smoothness.

Finally, the editorial board expresses its heartfelt thanks to more than 200 contributors, who offered their skills, effort, insight, and scholarship to Russia's Great War and Revolution. At the risk of tautology, it must be said that this series could not have come to fruition without them. Their efforts-and patience with an extended production schedule-allowed us to present our readers with strong evidence for the enduring importance and complexity of this eight-year span in the history of Central and Eastern Europe and Asia, the consequences of which continue to shape our world in ways that we are still witnessing.

Anthony Heywood

David MacLaren McDonald

John W. Steinberg

June 2014 